\title{
Az UNIÓS ROMA OKTATÁSPOLITIKA - MAGYAR TANULSÁGOK
}

\author{
CSERTI CSAPÓ TIBOR \\ Pécsi Tudományegyetem Bölcsészettudományi Kar, Neveléstudományi Intézet, \\ Romológia és Nevelésszociológia Tanszék
}

Magyarországon már az Európai Unióhoz történő csatlakozása előtt is, azóta viszont még hatványozottabban számos intézkedés történt a cigány népesség társadalmi-gazdasági helyzetének javítására, a társadalmi lemaradás mérséklésére. Mindemellett a statisztikák, de benyomásaink a mindennapokról is azt sugallják, markáns változás nem következett be az esélyek különbözőségében. A jogszabályi környezet megváltoztatása, a támogató programok, az uniós források bevonása nem hozott átütő eredményt.

A tanulmány e támogató mechanizmusokról nyújt áttekintő képet, s arra keresi a választ, mit mutatnak a statisztikai adatok, mennyire adnak pontos és objektív képet a roma népesség helyzetéről, annak változásáról.

Kulcsszavakः roma, társadalmi integráció, oktatás, esélyegyenlőség

Even before and after joining to the European Union in Hungary several measures have been taken to improve the socio-economic situation of the Roma population and to reduce their social backwardness. However the statistics, but our impressions of everyday life too suggest that there has been no characteristic change in odds. Changing the legal environment, supporting programs, and involving EU funds have not yielded a breakthrough.

The study provides an overview of these support mechanisms and seeks to find out what the statistical data show, how reflects these data accurate and objective the situation of the Roma population and about its changes.

Keywords: Roma population, social inclusion, education, equal opportunities

Levelező szerző: Cserti Csapó Tibor, Pécsi Tudományegyetem Bölcsészettudományi Kar,

Neveléstudományi Intézet, Romológia és Nevelésszociológia Tanszék, 7624 Pécs, Ifjúság útja 6.

E-mail: cserti.csapo.tibor@pte.hu 


\section{Bevezetés}

$\mathrm{A}$ zt nem állíthatjuk, hogy a magyarországi romák társadalmi beilleszkedésének elősegítésére irányuló politikát az Európai Unióhoz történő csatlakozás generálta és kényszerítette ki, hiszen a cigányság helyzetének javítására irányuló intézkedések már a rendszerváltást követő időszakban jelen voltak, s némelyiknek (mint pl. az 1993. évi LXXVII. Törvény a nemzeti és etnikai kisebbségek jogairól) gyökerei visszanyúlnak a pártállami éra végére. Inkább egyfajta folyamatos szerves törekvésként értelmezhetjük a romaintegráció megoldási kísérleteit. Ennek a folyamatnak az Unióhoz történő csatlakozás időszaka, a közösség elvárásai természetesen új lendületet, irányokat adtak, új kezdeményezéseket, akciókat indítottak el.

Az 1990-es évekből példa a már említett 1993. évi törvény, elsősorban érintve a kulturális autonómiát, ebbe értve az oktatás területén megjelenő azonos jogosítványok rendszerét. De a jogszabályi fejlődés eredménye a kisebbségi önkormányzati rendszer kiépítése is. A jogi lépések mellett a mindennapi élet, a tényleges társadalmi felemelkedés előmozdításának is megvoltak a maguk kezdeményezései. Nyilván ott rejlik mögöttük a fejlett európai térséghez közeledni kívánó posztszocialista országok igazodási törekvése az Unió emberi jogi légköréhez, antidiszkriminációs elvárásaihoz.

E tanulmány ezen integrációs törekvések bemutatására tesz kísérletet, kiemelten fókuszálva a romák oktatási lemaradásának mérséklése, az iskolázottság emelése érdekében tett kezdeményezésekre. Amellett, hogy ezeket a teljesség igénye nélkül áttekintjük, kíváncsiak vagyunk arra is, látszanak-e az uniós csatlakozás 15. évfordulójához közeledve változások a hazai cigányság mindennapjaiban, helyzetében, mely források alapján, s hogyan értelmezhetők ezek a változások, s azok a statisztikai adatok, amelyek segítségével képet alkothatunk a cigányság helyzetéről.

\section{$\mathrm{A} z$ Európai Unió romaintegrációs elvárásai}

A romák társadalmi befogadásának kérdése uniós szinten közvetlenül azt megelőzően került különösen a fókuszba, mielőtt számos közép- és kelet-európai állam - némelyikük jelentős roma népességgel rendelkezik - 2004-ben, illetve 2007-ben csatlakozott volna az Európai Unióhoz. A kontinensen élő 8,5-10 millió fő közé becsült cigányság (vö. Szabóné 2008: 415), ebből az Európai Unió területén ma élő, a becslések szerint 6,2 millió fót számláló roma népesség ( $E S z$ 2016: 23) jelentős része Szlovákia - népszámlálás 2011: 105738 fö (Kapitány 2013: 49), becsült 400000 fö (Vaňo 2011, id. Hangácsi 2013: 114) -, Magyarország - népszámlálás 2011: 315583 fő (KSH 2014: 16), becsült 876000 fö (Pénzes-Tátrai-Pásztor 2018: 3) -, majd 2007-ben Románia - népszámlálás 2011: 622000 fó (Kapitány 2013: 41), becsült 1220000 fó (Papp 2010: 135) - és Bulgária - 2001. népszámlálás: 746664 fö (Sándor-Schmidt 2016: 63), becsült 700-800 000 fö (Roma Education Fund 2007: 9) - belépésével válik uniós állampolgárrá (ESz 2016: 8).

$\mathrm{A} z$ EU működéséről szóló szerződés tartalmazza a társadalmi kirekesztés és a hátrányos megkülönböztetés elleni küzdelmet. Emellett védelmezni kell az Európai Unió Alapjogi Chartájában, valamint a Szociális Chartában megállapított szociális jogokat (FRA 2014: 7). Már a Magyarországgal kötött csatlakozási partnerségi megállapodás középtávú politikai prioritássá tette a roma népesség integrációját (ESz 2016: 23). Az 
első olyan jelentős uniós szintű dokumentumot, amely a romák integrációjának kérdésével foglalkozott, 2011 áprilisában adták ki, s ez a nemzeti romaintegrációs stratégiák uniós keretrendszeréről szóló bizottsági közlemény volt (ESz 2016: 24). Javasolta, hogy minden tagállam saját nemzeti romaintegrációs stratégiát készítsen ( $E S z$ 2016: 25). A stratégiáknak célzott fellépéseket és az azokhoz szükséges finanszírozással kapcsolatos információkat is kellett tartalmazniuk. Továbbá le kellett fektetniük egy megbízható, a romák számára konkrét eredményeket biztosító monitoring mechanizmus alapjait (ESz 2016: 28).

Az Európa Tanácsnak a roma gyermekek oktatásáról szóló ajánlása arra hívja fel a tagállamokat, hogy garantálják a minőségi oktatáshoz való, megkülönböztetéstől mentes hozzáférést, biztosítsanak minőségi kora gyermekkori nevelést, csökkentsék a középfokú oktatásból lemorzsolódók számát, és adjanak támogatást a roma diákok különféle igényének a kielégítésére. Az Európai Bizottság 2013. júniusban arról számolt be, hogy több uniós tagállam még mindig nem teljesítette a feltételek némelyikét, különösen az oktatás terén, ahol a szegregáció továbbra is széles körben elterjedt (EC 2013a). A Bizottság 2013-ban öt tagállamhoz - Bulgária, a Cseh Köztársaság, Magyarország, Románia és Szlovákia - intézett országspecifikus ajánlásokat (EC 2013b) a romák befogadásáról, és ezekben a minőségi, befogadó többségi oktatáshoz való tényleges hozzáférés biztosítására helyezte a hangsúlyt, már az iskola előtti neveléstől kezdve (FRA 2014: 7).

A helyzet tehát hazánkban sem megnyugtató Brüsszelből nézve sem. Ezért indokolt megvizsgálnunk, milyen lépések történtek Magyarországon az oktatási integráció elősegítésére, s ezeknek itthonról látszik-e a hatása.

\section{Oktatási integrációs törekvések hazánkban a csatlakozást megelőzően}

A rendszerváltás utáni két évtized legfontosabb intézkedéseit a cigány/roma lakosság oktatásával kapcsolatban két, egymástól nagyon eltérő iránnyal írhatjuk le: az 1993-ban született törvényben az állam biztosította minden nemzetiség és etnikum számára a saját kultúra és nyelv ápolását az iskola keretein belül is. Emellett pedig a cigány gyerekek számára felzárkóztató és tehetséggondozó programokat tett lehetővé. „Tehát jelen esetben a kultúraápolás és a hátrányok leküzdésére létrejövő programokat egyszerre, ugyanazon célcsoporton alkalmazzák, így mosva össze egy etnikai csoportot egy szociális jellemzőkkel leírható csoporttal" - fogalmaz Varga Aranka 2012-es tanulmányában. Így alakulhatott ki az a közvélekedés, hogy a hátrányos helyzetű tanuló egyben cigány/roma származású is. Ez természetesen nem igaz, hiszen a szociológiai kutatások alapján a kb. 700000 fönyi mélyszegénységben élő ember egyharmada tartozik a cigány/roma kisebbséghez (Trendl 2018: 160).

Az oktatási felzárkózás érdekében tett lépések közül meg kell említeni, hogy a Soros Alapítvány 1993-ban megalapította az első olyan ösztöndíjat, amely a közép- és felsőoktatásban tanuló cigány diákokat támogatta (Forray 2013: 10). Pécsett a Gandhi Gimnázium megalapítása 1994-ben szintén e lépések sorába illeszkedik. A Romaversitast 1996ban a Roma Polgárjogi Alapítvány alapította (Forray 2013: 15). Majd 2000-ben létrejött a PTE Romológia Tanszéke. Ez évben indult a hátrányos helyzetü, tehetséges diákok továbbtanulását segítendő az Arany János Tehetséggondozó Program is (Fehérvári-Varga 2018: 12). A Wlislocki Henrik Roma Szakkollégium (WHS), a Pécsi Tudomány- 
egyetem BTK Romológia Tanszék mellett a 2001/2002-es tanévben indult (Forray 2013: 16), s vált a felsőoktatásban tanuló roma származású diákok lemorzsolódást gátló és az előrehaladást segítő terepévé.

Liskó Ilona 2006-ban megjelent tanulmánya (idézi: Trendl 2018: 160) a 2002 után kezdett intézkedések eszközrendszerét három csoportba osztotta.

1. Politikai eszközök:

- 2002: miniszteri biztos és hivatal felállítása

- kormányzati intézkedések a kirekesztés ellen

- 2003: az oktatási törvény módosítása: az iskolai szegregáció tilalma

- 2005: törvénymódosítás tiltja az általános iskolai felvételi szelekciót

- 2007: felvételi tiltása és a körzeten kívülről jelentkezők közül a hátrányos helyzetü, halmozottan hátrányos helyzetű tanulók előnyben részesítése

2. Finanszírozási eljárások:

- bevezetik a „hátrányos helyzet” kategóriáját a juttatások elosztásánál

- integrációs normatíva bevezetése az általános iskolák részére

- Országos Oktatási Integrációs Hálózat (2003) létrehozása az inkluzív pedagógiai kultúra terjesztése és a szegregációs formák felszámolása céljából; 45 bázisintézmény; kistérségi koordinátor

- Pályázatok kiírása: HEFOP, Bursa Hungarica, Macika, Romaversitas

3. Pedagógiai eljárások és programok:

- 2005: Útravaló programok: ösztöndíjrendszer

Ahogy látjuk, keverednek itt a direkt etnikai célú támogatások azokkal, amelyek a szocioökonómiai státusbeli megközelítést helyezik előtérbe. Kétségtelenül mindkettőre szükség van.

A fentieket kiegészíthetjük még azzal, hogy 2004-ben megtörtént az Arany János Tehetséggondozó Program kibővítése a Kollégiumi Alprogrammal, illetve az Arany János Programot szakiskolákra is kiterjesztették (Trendl 2018: 160).

\section{Oktatási integrációs törekvések hazánkban a csatlakozás után}

A 2004-es csatlakozás utáni időszak egyik legátfogóbb kezdeményezése a közép-keleteurópai térségben élő romák társadalmi befogadásának előmozdítására a 2005-2014 közt zajló Roma Integráció Évtizede program volt. A résztvevő országok miniszterelnökei a 2005-2014 közötti időszakot a Roma Integráció Évtizedévé nyilvánították (Cserti Csapó 2017b: 134). Célja, hogy felgyorsítsa a romák társadalmi és gazdasági integrációját, és egyben hozzájáruljon a romákról alkotott kép pozitív irányú átalakulásához (Kurt Lewin Alapitvány, 2010).

A z Évtized négy prioritási területre fókuszált: az oktatás, foglalkoztatás, egészségügy és lakhatás területeire. Továbbá a szegénység, diszkrimináció és a nemi esélyegyenlőség problémáira is válaszokat kívánt nyújtani. A tagországok mindegyike kialakította RIÉP Akciótervét, amely célokat és indikátorokat határozott meg a prioritási területeken. A program központi eleme az ún. Roma Oktatási Alap (Roma Education Fund, 
$R E F$ ), amelyet 2005-ben hoztak létre azzal a céllal, hogy szélesítse a roma emberek oktatási lehetőségeit Közép-Kelet-Európában (Cserti Csapó 2016a: 7).

$\mathrm{A} z$ oktatás területén a RIÉP keretében zajló programok célja hazánkban a hátrányos helyzetű roma gyermekek, tanulók óvodai, iskolai sikerességének elősegítése, az oktatási szolgáltatásokhoz való egyenlő hozzáférés biztosítása. Hazánkban ezt a célt a hátrányos helyzetü, 0-4 éves korú gyerekeket és családjaikat célzó Biztos Kezdet Programmal; az óvodába nem járó, leginkább rászoruló gyerekek intézményekbe kerülését célzó Óvodáztatási támogatással; az iskolán kívüli foglalkozás keretében elsősorban a halmozottan hátrányos helyzetủ tanulók, főként a romák iskolai sikerességét, továbbtanulását elősegíteni hivatott Tanoda programmal; a tehetséges, de nehéz körülmények között élö, hátrányos helyzetű diákok iskolai előrejutását segítő Útravaló Ösztöndijprogrammal; a hátrányos helyzetü, a formális iskolarendszerből lemorzsolódott roma fiatalok, felnőttek számára a képzés foglalkoztatási elemmel való összekapcsolása révén alternatív tanulási útvonalakat nyújtó Képzésbe Ágyazott Foglalkoztatással (Mayer 2009) igyekezett a kormányzati stratégia elérni (Cserti Csapó 2016a: 16-17).

Fontos lépés az is ebben az időszakban, hogy a felsőoktatás rendszerében 2011-ben a kormányzat létrehozta a Keresztény Roma Szakkollégiumi Hálózatot. Jogszabályi legitimációjuk a 2011-es felsőoktatási törvényben (2011. évi CCIV. törvény a nemzeti felsőoktatásról) való nevesítéssel történt meg, és ugyanekkor kezdődött meg célzott anyagi támogatásuk is (Varga 2015: 118). Bár a roma szakkollégiumok alapítása nem újkeletü, hisz 1998-ban hozták létre a Romaversitas Alapítvány Láthatatlan Kollégiumát, majd a 2001/2002-es tanévben a Pécsi Tudományegyetemen a Romológia és Nevelésszociológia Tanszéken dolgozók megalapították a Wlislocki Henrik Szakkollégiumot, ez az országos kezdeményezés mégis hiánypótló, hiszen a felsőoktatásban azelőtt kifejezetten cigány/roma diákok számára nem létezett ilyen típusú hálózat (Trendl 2018: 161).

A z említett szakkollégiumok támogatják a diákjaik diplomához jutását, és különböző eszközökkel próbálják a közoktatásból hozott hátrányaikat kompenzálni (Varga 2015: 189). Jelenleg tizenegy ilyen roma szakkollégium müködik az országban (Trendl 2018: 161).

\section{Eredmények a számok tükrében}

A kérdés, hogy a fentebb a teljesség igénye nélkül felsorolt erőfeszítések át tudták-e formálni érzékelhető mértékben a hazánkban élő romák életkörülményeit, javítani tudták-e társadalmi-gazdasági esélyeiket, csökkentették-e számszerűen a lemaradásukat. Nehéz objektív képet alkotni az elért eredményekről, a kezdeményezések hatékonyságáról (Cserti Csapó 2016b: 6), hiszen a romák társadalmi helyzetéről a számos módszertani, mérési problémával küzdő szociológiai kutatások, kormányzati jelentések nem adnak jól körvonalazódó képet. Ezt tovább nehezíti, hogy miközben az Unió integrációs elvárásai roma szemszögből fogalmazódnak meg, a programok jelentős része, s az ezekre irányuló mérések is a hátrányos helyzetű csoportokra fókuszálnak. $S$ bár jól tudjuk, a hazai romák jelentős része (mint a környező államokban mindenütt) beletartozik e körbe, a két megközelítés (etnikus és társadalmi státusbeli) azért koránt sincs teljes átfedésben ( $v \ddot{o}$. Arató 2007).

Mindezen dilemmák ellenére az elemzők egy része elég kritikusan tekint a romaintegrációs törekvések elért eredményeire. 
A roma népesség egészének iskolázottsága Magyarországon - de Európa többi országában is - még mindig jelentősen elmarad a megfelelő korúak általános iskolázottsági szintjétől (Brüggemann 2012). S bár váltig igaz - fogalmaz Maja Miskovic (2013: 8, idézi: Kozma 2013: 137) -, hogy a roma népesség kiútja az iskola, aközben az is mind világosabb, hogy a különböző „roma stratégiák” nem vagy csak igen keveset segítettek. Maja Miskovic szerint az integrációs stratégia pont az ellenkezőjére fordult az Unióban, marginalizálta a romákat, akik maguk is egyre kevésbé kívánnak bekapcsolódni az oktatásba.

Bernard Rorke és munkatársai a Roma dekád eredményeit vizsgáló statisztikák kapcsán maguk is kételyeiknek adnak hangot, nem elörelépés történt, de a legtöbb partnerországban a társadalmi távolság ezen időszak alatt még növekedett is (Rorke-MatacheFriedman 2015).

S miközben a szociológiai kutatások rendre a hazai cigányság körében megfigyelhető (bizonyos területeken) javuló iskolázottsági folyamatokra mutatnak rá (vö. Hajdu-Kertesi-Kézdi 2017; Kemény-Janky-Lengyel 2004), Polónyi István azért felhívja a figyelmet arra is, hogy a roma és nem roma népesség iskoláztatási esélyei közötti különbségeket tükröző üvegplafon index (GCI) azt mutatja, hogy csak bizonyos szintig - jellemzően az általános iskola befejezése utáni továbbtanulásig - javultak ezek az esélyek. Az érettségi, de még inkább a diploma megszerzése terén továbbra is jelentős akadályokba ütközik a cigány fiatal. A teljes hazai népesség és a romák iskolázottsági mutatóit elemezve látszik, hogy azonos szintü végzettség megszerzésére 0,201 annyi esélye van egy cigány embernek (Polónyi 2016: 108) (azonos esélyek esetén 1 volna a GCI mutató). Így van ez a fiatal korcsoportnál is, akik bár ebben a jogszabályokkal és programokkal támogatott környezetben nőttek már fel, de az üvegplafon talán csak egy árnyalatnyival vékonyodott fejük felett. A fiatal roma népesség iskolázottságában észlelhető üvegplafon hatás 0,265 (Polónyi 2016: 108). S az idősoros adatok sem jelzik ennek a hátrányhelyzetnek a jelentős mérséklődését. A magyarországi roma népesség iskolázottságában észlelhető legalább szakiskolai végzettségre számított GCI-hatás 2001-ben 0,269, 2011-ben 0,284 volt, s a tendencia 2021-re is csak a 0,319-es érték elérését prognosztizálja (Polónyi 2016: 109).

\section{A romaintegráció statisztikái}

Hogy a statisztikai adatok alapján valamiféle képet alkothassunk az elmúlt évtizedek romaintegrációs folyamatairól, két eszközrendszert javasolhatunk. Az első a társadalmi makrostatisztikák szintje, amelyek jellemzőbben kevesebb pozitív eredményt tudnak kimutatni. A második módszernél viszont folyamodjunk a helyi történések, folyamatok vizsgálatához és számszerü eredményeihez, amelyek azért arról tanúskodnak, hogy egyegy kezdeményezés nyomán pozitív változások, számszerü eredmények is felmutathatók.

\section{Makrostatisztikák}

Hajdu, Kertesi és Kézdi (2017: 271) tanulmányukban megállapítják: „A vizsgált két évtized alatt a roma fiatalok iskoláztatásában bámulatos mértékü fejlődés történt: az általános iskolai lemorzsolódás minimálisra (23\%-ról 7\%-ra) szorult vissza, a középiskolába beíratottak aránya pedig 23\%-ról csaknem 90\%-ra emelkedett. [...] Amíg az 1971-ben született roma kohorsznak minimális esélye volt középfokú végzettséghez jutni [...], 
addig a rendszerváltás után született generáció egynegyedének van ma már szakiskolai végzettsége, és több mint egyötödének érettségije."

A Roma Integráció Évtizede partnerei között részt vevő kormányok különböző módokon igyekeztek képet kapni a romák társadalmi helyzetéről. Miután egységesített és rendszeres statisztikai adatgyưjtés nem érhető el a roma népesség társadalmi mutatóiról, a legkülönbözőbb, de az egyes országokban nem feltétlenül egységesen képzett adatbázisokat emeltek be az adatgyüjtésbe (népszámlálás; egyéb adatfelvételek; állami intézmények által gyűjtött adminisztratív adatbázisok; roma és nem roma civil szervezetek beszámolói és jelentései stb.) Ezek azonban az egyes partnerországokban nem feltétlenül állnak rendelkezésre, nem egységesek és nehezen összehasonlíthatók. A partnerek a statisztikai módszertani problémák és dilemmák miatt egy olyan módszertani mérési gyakorlat kidolgozására törekedtek, amely a romák társadalmi integrációjának mérhetővé tételét és az egyes országok közötti összehasonlításokat, valamint az időbeli változások nyomon követését is lehetővé teszi (Cserti Csapó 2018a: 577). Az Évtized keretében kidolgozott és használatra javasolt index a már meglévő adatoknak a kezelésére, összehasonlítására, értelmezhetőségére fókuszáló adatközlési forma. Ennélfogva magában hordozza a felhasznált adatbázisok összes problémáját, azok adathiányait, reprezentativitási hibáit.

A vizsgálat eredményeit mindenképpen óvatosan kell kezelni. Arra biztosan nem alkalmasak, hogy az országok közötti összevetéseket megtehessük a társadalmi beilleszkedés értelmezéséhez, viszont véleményünk szerint jól felhasználhatók arra, hogy az egy-egy országon belül a dekád ideje alatt tapasztalható változásokra, azok nagyságára, valamint pozitív, vagy negatív tendenciáira rávilágítsanak.

$\mathrm{A} z$ indikátorok értelmezésénél azt is figyelembe kell venni, hogy a többségi népesség és a cigány lakosság társadalmi távolságát jelző értékek nem az abszolút életkörülményekről adnak tájékoztatást. Sokkal inkább szubjektív adatok, amelyek a viszonylagos lemaradásra mutatnak rá a cigány csoport vagy azon belül a roma nők esetében. Például előfordulhat, hogy egy viszonylag fejlettebb ország össztársadalomra vonatkozó mutatóihoz képest erőteljes lemaradást képviselő roma populáció helyzete objektív szinten mégis sokkal jobb, mint egy, a teljes népesség esetében alacsonyabb fejlettségi értékekkel jellemezhető szinthez képest viszonylag kisebb lemaradást elszenvedő roma népesség tagjainak a helyzete. (Vö. Cserti Csapó 2016a: 8-12, 2018a: 577-579; Roma Inclusion Index 2015.)

\section{RIÉP-eredmények, tendenciák}

Az értékelés során táblázatos formában közöljük a 2005-ös bemeneti bázisév adatait az egyes mutatók tekintetében a teljes népességre, a roma népességre, valamint, ahol rendelkezésre állt ilyen adat, ott a roma nőkre vonatkozóan külön is. Az évtized zárásakor felvett 2014-es kimeneti adatokat ugyanilyen bontásban ismerhetjük meg. A táblázat utolsó oszlopai a roma népességnek a teljes népességhez viszonyított lemaradását mutatják a bázisévben és a záró évben, a végső adat pedig arra világít rá, hogyan változott az időszak alatt ez a társadalmi távolság. Az adatközlés jellege miatt az utolsó oszlop adatai negatív előjel esetén fejlődő folyamatról, kedvező változásokról tanúskodnak, hiszen arra mutatnak rá, hogy a szakadék csökkent. A pozitív érték viszont a roma csoportnak a többséghez viszonyított lemaradásában a kirekesztődő, rosszabbodó tendenciára hívja 
fel a figyelmet! Azt is meg kell jegyezni, hogy a változást jelző számok önmagukban nem informatívak, csak ha azok hátterét, okait is értelmezzük.

A dekád méréseinek adatai alapján elmondható, hogy a hazai eredmények korlátozottnak látszanak. Miközben az írni-olvasni tudás kérdése nem probléma Magyarországon (alig van elmaradás a romák esetében) és az óvodai inklúzió terén is jelentős javulás figyelhető meg a vizsgált időszakban, az oktatás többi mutatója terén romló tendenciák rajzolódnak ki. Sokat (42\%-ról 70\%-ra) javult a roma, cigány óvodás korú gyerekek közt azok aránya, akik részt vesznek az iskolai előkészítésen. A lemaradásban korábban tapasztalt hatalmas érték jelentős csökkenése tény. De mi vezetett ehhez? Változott közben az óvodai beíratást szabályozó törvényi környezet (Nkt. 2011), a kormányzati törekvés, hogy a gyermekek már ne csak az eddig kötelező 5 éves kortól járjanak óvodába. (Igaz, csak 2015, szeptember 1-jétől lépett hatályba.) Eddig is kötelező volt ugyan az iskola-elökészítő év minden megfelelő életkorú kisgyereknek (Kt. 1993), ám lehet, hogy a 2005-ös év nagy eltérése ennek eredményességét illetően a teljes népesség és a romák közt abból adódik, hogy a nem megfelelő szocioökonómiai státuszból érkező gyermekek nagyobb arányban nem tudták egy nevelési év alatt behozni lemaradásukat s elérni az iskolaérettséget, így magasabb arányban tartották őket vissza az óvodákban, rontva a statisztikai értéket. Lehet, hogy a 2014-es érték záruló ollója mögött az áll, hogy a hátrányos helyzetü cigány családokból érkező óvodások közt is szélesebb körűvé vált, már a törvényi változás előtt is, hogy nem csak az utolsó kötelező évet töltik az óvodában, így iskolaérettebbé válva nagyobb arányban kerülhettek első osztályba a megfelelő életkort elérve. Lehet, hogy az óvodapedagógusok ítélnek enyhébben az iskolaérettséget illetően, hiszen ha most már nem csak egy évig vannak jelen a cigány, roma gyerekek, de a kis- és középső csoportokban is, az eleve megváltoztatja az óvoda etnikai arculatát, arányait, magával hozva a vélt vagy valós problémákat, konfliktusokat. S egyértelmüen látszik, hogy az olló záródását a többségi társadalom beiskolázási statisztikájának csökkenése is eredményezi. Lehet, ez egy stratégia, s nem eredménytelenség, hiszen tudjuk, bár a törvény (Nkt. 2011) újra a hatéves korban történő iskolakezdést preferálja, mégis egyre gyakoribb, hogy a középosztálybeli vagy gazdagabb szülők el tudják érni, mégiscsak maradjon a gyermek még az óvodában és „érjen még egy kicsit”. Nos, a mérörendszer a megfelelő életkorú - hazánkban tehát 6 éves - korcsoporthoz viszonyítva a beiskolázás arányát, az előbbiek miatt nyilván rosszabb értéket regisztrál.

A z írni-olvasni tudást mérő sor értékei is - dacára annak, hogy viszonylagos integráltságra utalnak - kétségesek, mert nem vizsgálták, milyen szintű íráskészség ez, pusztán technikai vagy funkcionális kompetencia is egyben?

A társadalmi távolság azonban összességében növekedett az oktatás-nevelés további színtereinek értékeit figyelembe véve. A cigány népesség jelentős része nem fejezi be az oktatás különböző szintjeit. Valószínűleg a tanköteles kor csökkentése is hozzájárul ahhoz, hogy míg az évezred elején az általános iskolát befejezők arányában alig volt elmaradás a hazai átlagos mutatókhoz viszonyítva, addig 10 év elteltével a cigány, roma családok gyermekei közül ez csak 77\%-nak adatik meg, s 10 diák közül kettő úgy került ki az iskolapadból az utóbbi tanévekben, hogy nincs meg a 8 általános iskolai bizonyítványa sem. (Látszik, ez picit érinti a teljes populációt, de a hátrányaik miatt gyakrabban túlkorossá váló roma tanulókat nagyobb mértékben.)

Hasonlóan nőtt az esélyegyenlőtlenség a középiskolai végzettség megszerzése terén is. Ez a mutató a dekád során látványosan emelkedett a teljes népességre nézve (isko- 
1. táblázat: A Roma Inclusion Index hazai oktatási mutatói

\begin{tabular}{|c|c|c|c|c|c|c|c|c|c|}
\hline \multirow[t]{2}{*}{ Mutató } & \multicolumn{3}{|c|}{$2005^{\mathrm{a})}$} & \multicolumn{3}{|c|}{$2014^{\text {b) }}$} & \multirow{2}{*}{ 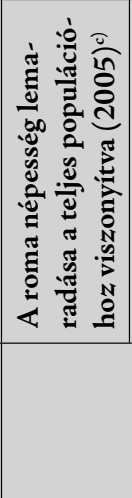 } & \multirow{2}{*}{ 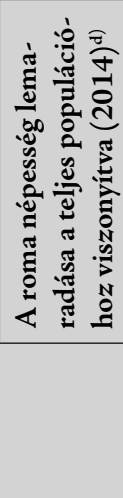 } & \multirow{2}{*}{ 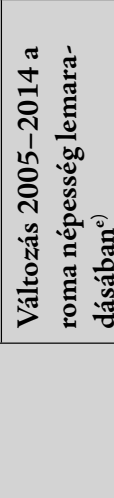 } \\
\hline & 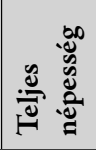 & 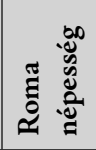 & 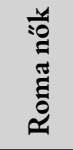 & 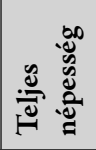 & 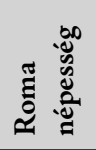 & 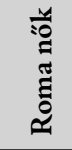 & & & \\
\hline \multicolumn{10}{|c|}{ OKTATÁS } \\
\hline $\begin{array}{l}\text { Iskolaelőkészítő } \\
\text { oktatás befejezé- } \\
\text { si aránya }\end{array}$ & 88 & 42 & n. a. & 69 & 70 & 67 & 46 & 1 & -45 \\
\hline $\begin{array}{l}\text { Alapfokú okta- } \\
\text { tás befejezési } \\
\text { aránya }\end{array}$ & 99 & 96 & n. a. & 96 & 77 & 73 & 3 & 19 & +16 \\
\hline $\begin{array}{l}\text { Középfokú } \\
\text { oktatás elvégzési } \\
\text { aránya }\end{array}$ & 51 & 15 & n. a. & 69 & 19 & 16 & 36 & 50 & +14 \\
\hline $\begin{array}{l}\text { Felsőoktatás } \\
\text { elvégzési aránya }\end{array}$ & 13 & 1 & n. a. & 18 & 1 & 1 & 12 & 17 & +5 \\
\hline $\begin{array}{l}\text { Írástudók } \\
\text { aránya }\end{array}$ & n. a. & n. a. & n. a. & 98 & 95 & 94 & n. a. & 3 & n. $a$. \\
\hline $\begin{array}{l}\text { A diákok elkülö- } \\
\text { nítése a speciális, } \\
\text { gyógypedagógiai } \\
\text { iskolákban }\end{array}$ & n. a. & 15 & n. a. & n. a.. & n. a.. & n. a.. & 15 & n. a. & n. a. \\
\hline $\begin{array}{l}\text { A szegregált } \\
\text { iskolákban elkü- } \\
\text { lönített tanulók } \\
\text { aránya }\end{array}$ & n. a. & 13 & n. a. & n. a.. & 20 & n. a.. & 13 & 20 & +7 \\
\hline
\end{tabular}

a) Forrás: Roma Inclusion Index, 2015

b) Forrás: Roma Inclusion Index, 2015

c) Saját számítás

d) Forrás: Polónyi 2016

e) Saját számítás

lai expanzió, demográfiai változások), a roma gyerekek közül is többen szereznek már érettségit 2014-re, de körükben jóval mérsékeltebb ez a javuló tendencia, így a különbség a teljes és a roma népesség közt végül is nőtt. Azt nem tudjuk, mekkora szerepe volt ebben a támogató programoknak, s mekkora a roma családokban zajló lassú érték- és normaváltásnak az oktatási rendszerrel, továbbtanulással kapcsolatban, vagy mennyiben 
járult hozzá a fiatal nemzedék körében tapasztalható demográfiai arányeltolódás miatt a középiskolák stratégiaváltása a felvételi célcsoportok irányába.

A felsőfokú végzettség megszerzése terén pedig elmondható, hogy nem lépett előbbre a roma közösség, ám a hazai összmutatók növekedtek (korábban 13\%, 2014-ben már a megfelelő korcsoport 18\%-a kapott diplomát), így a leszakadás növekedett. Miközben a mutató nem tudja érzékeltetni azt a nyilvánvaló folyamatot, hogy az egyetemeken, fóiskolákon egyre többen tanulnak cigány, roma diákok is - kis számuk hiába emelkedő, szignifikáns változást a makrostatisztikában nem tud elérni.

$\mathrm{A} z$ iskolai szegregáció is nőtt, s a speciális iskolákra vonatkozó egyetlen adat jelzi a romák folyamatosan kimutatható felülreprezentáltságát. Furcsának tűnhet az az érték is, amely az etnikailag elkülönült oktatás emelkedő nagyságát jelzi. (2005-ben a roma tanulók 13\%-a járt olyan iskolába, ahol a tanulók legalább 35\%-a roma származású, 2014-ben már 20\%-ukat érinti ez). Nyilván az oktatáspolitika deszegregációs törekvései közepette a hátrányosabb helyzetű iskolák, kisiskolák tanulói mozgásai, s az eltérő népesedési folyamatok állnak a háttérben. A két nem oktatási részvételében alacsony különbség mutatkozik a cigány, roma lányok kárára a középfokú végzettségig, ez a hátrány azonban a felsőoktatásba történő bekerüléskor eltünik (Cserti Csapó 2016a: 17-18).

Ha a Roma Integráció Évtizede program résztvevő országait sorrendbe tesszük roma népességüknek a többségi társadalomhoz az oktatás területén kirajzolódó lemaradása alapján - (az egyes mutatók terén tapasztalható szakadék alapján sorba raktuk az országokat, majd ezeket a sorrendi értékeket összesítve ábrázoltuk az 1. ábrán) -, akkor hazánk e ragsorban a 4. helyen állt 2005-ben. Vagyis Magyarországon volt tapasztalható a negyedik legkisebb távolság a teljes népességhez képest. 2014-re hazánk előrébb lépett a listán, $\mathrm{s}$ harmadik helyre került. Ez azonban nem jelent feltétlenül javuló tendenciát az oktatási részvételi esélyek terén, pont a mutató korábban említett relatív volta miatt. Csupán annyit jelent, hogy a partnerországok sorában már a harmadik legkisebb leszakadás volt rögzíthető az adatsor alapján.

Ha megnézzük ugyanis a többi ország mutatóit, akkor azt tapasztalhatjuk, hogy a környező államokban még több területen s nagyobb mértékben nőtt a lemaradás az évtized folyamán. Tehát Magyarország előrelépése e viszonylatban a romák kirekesztődésének kisebb mértékü növekedését hordozza csupán, s nem a tényleges javulást (3.ábra).

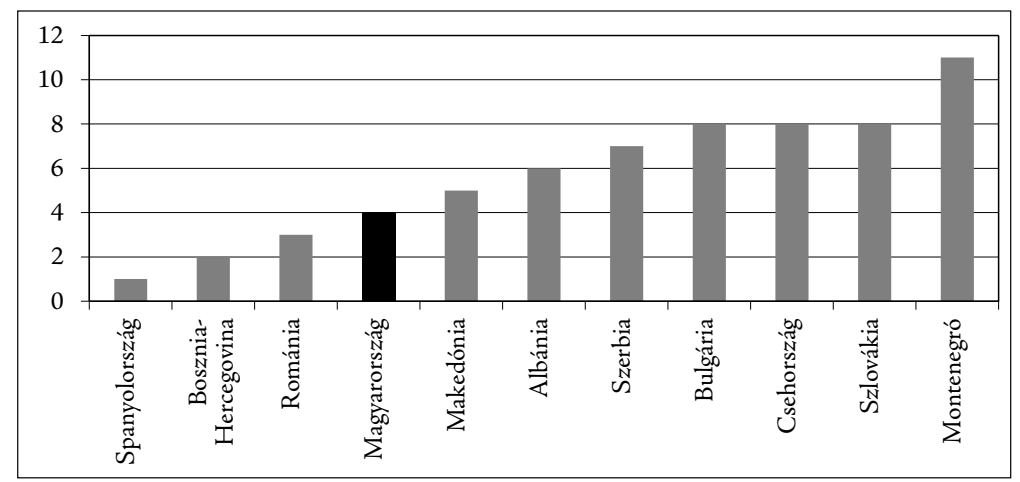

1. ábra: A Roma Integráció Évtizede program résztvevő országainak sorrendje roma népességüknek a többségi társadalomhoz viszonyított lemaradása alapján az oktatás területén (2005) 
A Roma Évtized partner országaiban ez a távolság Spanyolország esetében volt a legkisebb 2005-ben (1. ábra), s ez így is maradt a dekád zárásáig (2. ábra). Míg a legnagyobb szakadék a többségi és a kisebbségi csoport közt Montenegróban volt mind a kezdő, mind a záró évben.

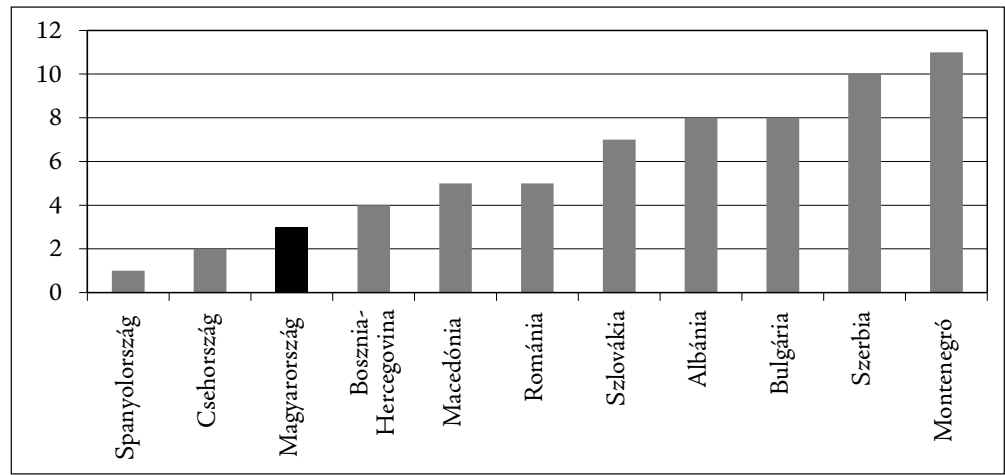

2. ábra: A Roma Integráció Évtizede program résztvevő országainak sorrendje roma népességüknek a többségi társadalomhoz viszonyított lemaradása alapján az oktatás területén (2014)

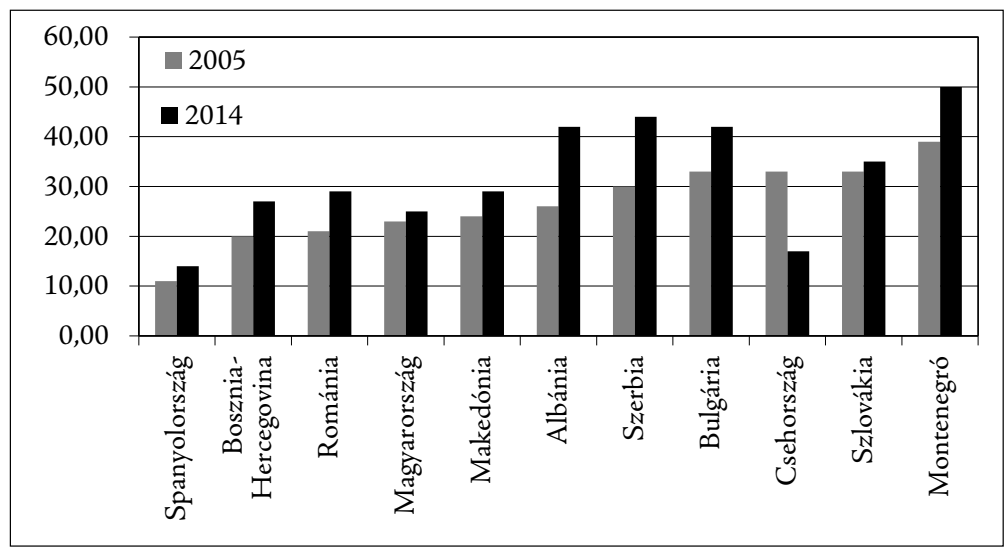

3. ábra: A roma népesség többségi társadalomhoz viszonyított lemaradásának változása az oktatás területén a Roma Integráció Évtizede program résztvevő országaiban (2005-2014)

Az egy-egy konkrét projekt, program hatékonyságát igazoló számadatok, mikrostatisztikák

Ha nem a nagy statisztikák kevésbé javuló mutatóit nézegetjük, helyette megnézzük, milyen programok müködnek hazánk cigányok által lakott térségeiben, ezek mit tesznek a mindennapokban a célcsoport társadalmi helyzetének javításáért, s milyen eredményeket tudnak felmutatni, máris jobb érzéssel gondolhatunk az elmúlt időszak erőfeszítéseire.

A tények igazolják a pozitív változásokat. Az, hogy a roma értelmiség bővülő számú tagjai egyre meghatározóbb és gyakoribb szereplői a közéletnek, hogy elindult, s halad előre egyfajta középosztályosodás a cigányság körében, s ennek jeleire a szociológiai vizs- 
gálatok tükrében kutatók mutatnak rá (vö. Forray-Orsós 2016; Forray 2017) - inkább érzékelhető, mint számokkal alátámasztható folyamatok.

A programok eredményei azonban számszerűsíthetők: A közoktatásban növekszik a nemzetiségi programok száma. A 2011/2012-es tanév során a nemzetiségi normatívát igénybevevők száma nőtt. 705 intézményben (372 óvoda, 301 általános iskola, 32 középiskola) 80954 gyermek számára szerveztek magyar nyelvű cigány nemzetiségi oktatást. A statisztikák szerint romani nyelvoktatást 6 óvodában, 11 általános iskolában és 12 középiskolában folytatnak, a beás nyelvet pedig 3 óvodában, 12 iskolában és 3 középfokú oktatási intézményben tanítják, összesen 2246 gyermek számára (Fórika 2015: 24; vö. Orsós 2015a: 14; Orsós 2015b: 166). Növekszik a nemzetiségi oktatásban részt vevő tanulók aránya is. Magyarország összes általános iskolájában 2009-ben a cigány nemzetiségi oktatásban részesülő tanulók aránya 6,5\% volt, 2012-ben már 7,5\%. (Vö. And 2015: 51.) S nyilván e programok léte még nem garancia az eredményes életre, de a kisebbségi identitás megerősödése, s ily módon majd a teljes értékű élet szempontjából fontosak.

Az Arany János Tehetséggondozó Programban - bár a célcsoport nem kimondottan roma, hanem a hátrányos helyzetü tanulók, a cigány diákok érintettsége miatt fontos mutató, hogy - a 2017/2018-as tanévben már 3929 diák (Hives 2018: 91) 23 müködtető intézményben (Fehérvári-Varga 2018: 244) volt jelen az ország elmaradottabb térségeiben.

Az oktatáspolitika törekszik arra, hogy a NAT, illetve a Kerettantervek elöírásainak megfelelően a hazai tankönyvek fejlesztése során a kisebbségekkel, így a cigánysággal kapcsolatos korrekt tartalmak is megjelenjenek a tankönyvekben (Andl-Cserti Csapó 2017: 28).

Ugyanilyen identitás- és presztízserősítő aktus volt a közép és emelt szintű érettségi bevezetése a 2004/2005-ös tanévtől mindkét hazai cigány nyelvből (Lakatos 2018: 101102), az államilag elismert nyelvvizsga a két hazai cigány nyelvből (Lakatos 2018: 102; Orsós 2018: 82-83) és e nyelvek megjelenése a felsőoktatásban (Lakatos 2018: 103; Orsós 2018: 82).

$\mathrm{Az}$ 1990-es évekhez képest a PTE-n, de az ország más egyetemein is egyre nagyobb számban tanulnak cigány, roma származású diákok, s ma már nem csak a klasszikusnak számító szakokon (romológia, szociális munka). A Wlislocki Henrik Szakkollégium ösztöndíjas hallgatói a 2013-2018 közötti időszakban pl. az egyetemnek mind a 11 karáról érkeztek (Trendl 2019).

A felsőoktatásban a roma szakkollégiumok országszerte hozzájárulnak hallgatóik si= keres diplomaszerzéséhez. Csak a PTE-n, a Wlislocki Henrik Szakkollégiumban a 20132018 közötti időszakban 35 fö fejezte be a tanulmányait eredményesen (Trendl 2019).

$\mathrm{A} z$ egyetemeken már nem egy helyen romológiai ismeretek is beépülnek a leendő pedagógusok képzési tartalmaiba, elősegítve ezzel a pályára lépés után a hatékonyabb munkát hátrányos helyzetű diákjaikkal. A már pályán lévő tanároknak továbbképzések keretében van lehetőségük ezen ismeretek elsajátítására.

Más szakterületeken is megjelent az igény ilyen ismeretek elsajátítására, hogy a hatékonyabb kommunikáció erősítse az esélyegyenlőség megvalósulását a mindennapok ügyintézése során. Jó példa erre a Baranya Megyei Rendőr-főkapitányságon évek óta zajló érzékenyítő program.

Nem szóltunk még a civil szervezetek széles körü tevékenységéről, melyek közül számtalan NGO tevékenykedik a helyi cigány, roma emberek jogi, esélyegyenlőségi, 
oktatási helyzetének és életkörülményeinek javítása terén - nem kevés eredményt felmutatva.

Fontos a tanodatevékenység helyi szinten a diákok iskolai sikerességének előmozdításában. A tanodák száma a 2006/2007-es tanévben 66 volt országszerte (Németh 2009: 11).

Apró, de helyi szinten vagy az érintett személyek életében fontos lépések és eredmények ezek, tapasztalataik, sikereik adaptálása és kiterjesztése révén bizonyára a makroszintű statisztikákban is változásokat indukálnak idővel.

\section{Összegzés}

Az elmúlt 25 év romaintegrációs törekvéseinek eredményeit tükröző statisztikák tehát elég ellentmondásosak.

Elemzésünk végén talán levonhatjuk azt a következtetést, hogy a hazai cigány, roma népesség elmúlt 25 éves oktatási integrálódottságát vizsgáló nagytársadalmi makrostatisztikák óvatosan kezelendők a folyamatok irányának és mértékének pontos érzékeltetésére. Azok módszertani hiányosságai, adatgyűjtési pontatlanságai, s az apró változásokat és eredményeket az adatsokaságba bemosó hatásai miatt nem láttatják a felszín alatti kisebb pozitív változásokat. A társadalmi távolság növekedésére vonatkozó riasztó számadatok vagy az azok információtartalmát esetenként túl nagyra értékelő elemzők riasztásai mindenképpen jelzésértékűek, de hasznos, ha az oktatási rendszer alegységeiben, helyi szinten zajló folyamatokat is elemezzük, értelmezzük, árnyaltabb képet rajzolva így a folyamatokról, a roma középosztályosodásról, társadalmi integrációról.

Hozzá kell az adatokhoz azt is tenni, hogy az oktatás területén indukált beavatkozások legtöbb esetben nem azonnal éreztetik a hatásukat - például az oktatási rendszer bemenetére - az óvodáskorra irányuló invesztíció is ilyen. Az talán látszik pl. a Roma Évtized első indikátorának alakulásából, hogy az óvodai nevelésben több országban megfigyelhető a pozitív változás. Ezek a gyerekek várhatóan sikeresebbek lesznek az iskolai tanulmányaik során is, fóként, ha az oktatás későbbi színterein további támogatásokban részesülnek. Az Évtized 10 vagy az Unióban eltöltött 15 éves időtávja azonban kevés arra, hogy a kezdeti befektetés végigfusson a teljes oktatási rendszer szintjein. A változások látszanak, jó irányok rajzolódnak ki. Elindultak olyan folyamatok, indukálódtak olyan kezdeményezések, amelyek hatásairól más eszközökkel (pl. interjúkkal, esettanulmányokkal, mélyfúrásos kutatásokkal) érzékletesebben alkothatunk képet. Ezek a programok szép ívet rajzoltak ki a cigány népesség oktatási integrációjának mezőjében az oktatási rendszer teljes spektrumán keresztül a szabályozók szintjén, a programok szintjén. Más kérdés, hogy ezek a napi gyakorlatba milyen hatásfokkal mennek át, s milyen változásokat eredményeznek a cigányság élethelyzetében. Jelzi a kormányzat elkötelezettséget, hogy a RIÉP négy fókuszterületét annak lezárulta után is fókuszban tartja, s további céltámogatásokkal segíti.

\section{IRODALOM}

Andi H. (2015) A kisiskolák és nemzetiségi oktatás összefüggésrendszerének néhány aspektusáról. Romológia folyóirat, No. 9. pp. 36-54. http://romologiafolyoirat.pte. hu/?page_id=1270 [Letöltve: 2019.01.24.] 
Andl H. (2018) Az Arany János Program vizsgálata - Kutatástörténeti vázlat. In: FEhérvári A. \& Varga A. (eds) Reziliencia és inklúzió az Arany János Programokban. Pécs, Pécsi Tudományegyetem Bölcsészettudományi Kar Neveléstudományi Intézet Romológia és Nevelésszociológia Tanszék, Wlislocki Henrik Szakkollégium. pp. 65-86. http://wlislocki.pte.hu/sites/wlislocki.pte.hu/files/files/ilovepdf_merged.pdf [Letöltve: 2019. 01. 26.]

Andl H. \& Cserti Csapó T. (2017) Cigányok, romák reprezentációja a hazai környezet- és természetismeret, illetve a földrajz tankönyvekben. In: Mrázı́ J. (ed.) A tanulás új útjai. Budapest, Magyar Nevelés- és Oktatáskutatók Egyesülete. pp. 28-46. http://hera.org. hu/wp-content/uploads/2014/02/HERA_evkonyv_kiegeszites20170615.pdf [Letöltve: 2019. 01. 27.]

Arató F. (2007) Pozitív diszkrimináció vagy megerősítő társadalmi törekvések? (Oktatáspolitikai diskurzuselemzés egy amerikai társadalmi vita kapcsán.) Új Pedagógiai Szemle, Vol. 57. No. 5. pp. 65-76. http://epa.oszk.hu/00000/00035/00113/ [Letöltve: 2019. 01. 30.]

Brüggemann, CH. (2012) Roma Education in Comparative Perspective. Findings from the UNDP/World Bank/EC Regional Roma Survey. Roma Inclusion Working Papers. Bratislava.

Cserti Csapó T. (2016a) Elillant évtized? A cigány, roma csoportok társadalmi integrációjának alakulása a kelet-közép-európai régió országaiban az oktatás területén a Roma Integráció Évtizede eredményeinek tükrében. Romológia, No. 11. pp. 10-28. http:// romologiafolyoirat.pte.hu/wp-content/uploads/2018/01/romologia_11_BELIV_ PRINT_FULL.pdf [Letöltve: 2018. 12.01.]

Cserti Csapó T. (2016b) Elillant évtized II. A cigány, roma csoportok foglalkoztatás-politikai integrációjának alakulása a kelet-közép-európai régió országaiban a Roma Integráció Évtizede eredményeinek tükrében. Romológia, No. 12. pp. 6-26. [Letöltve: 2018. 12. 01.]

Cserti Csapó T. (2017a) Elillant évtized III. A cigány, roma csoportok társadalmi integrációjának alakulása a lakhatási körülmények terén a kelet-közép-európai régió országaiban a Roma Integráció Évtizede eredményeinek tükrében. Romológia, No. 14. pp. 110-133. [Letöltve: 2018. 12. 01.]

Cserti Csapó T. (2017b) A Roma integráció évtizedének számszerűsített eredményei az oktatás és foglalkoztatás területén Közép-Kelet-Európában. In: Márfi A. (ed.) Cigánysors - A cigányság történeti múltja és jelene. III. Pécs, Erdős Kamill Cigánymúzeum Cigány Kulturális és Közművelődési Egyesület. pp. 134-163.

Cserti Csapó T. (2018a) A hazai cigány, roma népesség esélyegyenlősége az iskolarendszerben a Roma Integráció Évtizede eredményeinek tükrében. In: ENDRődy-NAGY O. \& FehÉrvári A. (eds): HERA Évkönyvek V.: Innováció, kutatás, pedagógusok. Budapest, Magyar Nevelés- és Oktatáskutatók Egyesülete; Hungarian Educational Research Association (HERA). (ISBN:978-615-5657-06-1) pp. 575-587. http://hera.org.hu/wpcontent/uploads/2014/02/HERA_Evkonyvek_V.pdf [Letöltve: 2018. 12. 01.]

Cserti Csapó T. (2018b) Elillant évtized IV. A Roma Integráció Évtizede Program eredményei, s a cigány, roma csoportok társadalmi integrációjának alakulása az egészségügy prioritási területén, illetve a horizontális vizsgálati témák tekintetében a kelet-közép-európai régió országaiban. Romológia, No. 16-17. pp. 98-123. [Letöltve: 2018. 12. 01.]

EC (2013a) European Commission: Proposal for a COUNCIL RECOMMENDATION on effective Roma integration measures in the Member States. Brussels, 26.6.2013 COM(2013) 460 final. http://ec.europa.eu/transparency/regdoc/rep/1/2013/EN/1-2013-460-

EN-F1-1.Pdf [Letöltve: 2019. 01.20.] 
EC (2013b) European Commission: EU country-specific recommendations. https://ec.europa. eu/info/business-economy-euro/economic-and-fiscal-policy-coordination/eu-economicgovernance-monitoring-prevention-correction/european-semester/european-semestertimeline/eu-country-specific-recommendations_en [Letöltve: 2019. 01.30.]

ESz (2016) Európai Számvevőszék: A romák integrációjával kapcsolatos uniós szakpolitikai kezdeményezések és pénzügyi támogatás: az elmúlt évtizedben jelentös elörelépések történtek, de a gyakorlatban további eröfeszitésekre van szükség. Különjelentés. https://www.eca. europa.eu/Lists/ECADocuments/SR16_14/SR_ROMA_HU.pdf [Letöltve: 2018. 12. 14.]

Európai Bizottság (2011) A nemzeti romaintegrációs stratégiák uniós keretrendszere 2020-ig. $\operatorname{COM}(2011) 173$ végleges, Brüsszel, 2011. április 5. http://ec.europa.eu/justice/policies/ discrimination/docs/com_2011_173_en.pdf. [Letöltve: 2019.01.12.]

Fenérvári A. \& Varga A. (2018) (eds) Reziliencia és inklúzió az Arany János Programokban. Pécs, Pécsi Tudományegyetem Bölcsészettudományi Kar Neveléstudományi Intézet Romológia és Nevelésszociológia Tanszék, Wlislocki Henrik Szakkollégium. http:// wlislocki.pte.hu/sites/wlislocki.pte.hu/files/files/ilovepdf_merged.pdf [Letöltve: 2019. 01. 26.]

FórIKA L. (2015) A cigány nemzetiségi oktatás helyzete a nemzetiségi oktatás rendszerében az ombudsmani jelentések tükrében. Romológia folyóirat, No. 9. pp. 8-27. http:// romologiafolyoirat.pte.hu/?page_id=1259 [Letöltve: 2019.01 .24 .]

Forray R. K. (2013) Cigány diákok a felsőoktatásban. Romológia folyóirat, No. 1. pp. 8-23. http://romologiafolyoirat.pte.hu/?page_id=495 [Letöltve: 2018. 12.14.]

Forray R. K. (2017) A cigányság középosztályosodása. Educatio, Vol. 26. No. 4. pp. 581590. (DOI: 10.1556/2063.26.2017.4.6) http://epa.oszk.hu/01500/01551/00102/pdf/ EPA01551_educatio_2017_04_581-590.pdf [Letöltve: 2019. 01. 12.]

Forray R. K. \& Orsós A. (2016) Roma jövő Magyarországon. Educatio, Vol. 25. No. 4. pp. 516-526. http://epa.oszk.hu/01500/01551/00098/pdf/EPA01551_ educatio_2016_4_516-526.pdf [Letöltve: 2019. 01.12.]

FRA (2014) Oktatás: a romák belyzete 11 uniós tagállamban. Felmérés a romákról - Középpontban az adatok. http://publications.europa.eu/resource/cellar/5db33bbf-e951-11e8b690-01aa75ed71a1.0001.02/DOC_2 [Letöltve: 2019. 01. 08.]

Hablicsex L. (2007) A roma népesség iskolázottságának területi alakulása: Tények és becslések. Kisebbségkutatás, No. 4. http://www.hhrf.org/kisebbsegkutatas/kk_2007_04/ cikk.php?id=1511 [Letöltve: 2016. 11.09. ]

Hajdu T., Kertesi G. \& Kézdi G. (2017) Roma fiatalok a középiskolában. Beszámoló a TÁRKI Életpálya-felmérésének 2006 és 2012 közötti hullámaiból. pp. 265-302. http:// old.tarki.hu/adatbank-h/kutjel/pdf/b334.pdf [Letöltve: 2019. 01. 15.]

HANGácsi Zs. (2013) Kisebbségben. A szlovákiai cigányok iskolai és társadalmi integrációjáról. In: Karlovitz J. T. (ed.) Társadalomtudományi gondolatok a harmadik évezred elején. pp. 11-119. (ISBN 978-80-971251-4-1) http://www.irisro.org/tarstud2013aprilis /21HangacsiZsuzsanna.pdf [Letöltve: 2018. 12. 19.]

Híves T. (2018) Arany János Programok és térségi összefüggéseik. In: FehÉrvári A. \& Varga A. (eds) Reziliencia és inklúzió az Arany János Programokban. Pécs, Pécsi Tudományegyetem Bölcsészettudományi Kar Neveléstudományi Intézet Romológia és Nevelésszociológia Tanszék, Wlislocki Henrik Szakkollégium. pp. 89-118. http://wlislocki. pte.hu/sites/wlislocki.pte.hu/files/files/ilovepdf_merged.pdf [Letöltve: 2019. 01. 26.]

Kapitány B. (2013) Kárpát-medencei népszámlálási körkép. Demográfia, Vol. 56. No. 1. pp. 25-64. http://demografia.hu/kiadvanyokonline/index.php/demografia/article/ viewFile/368/601 [Letöltve: 2019. 01. 12.] 
Kemény I., Janky B. \& Lengyel G. (2004) A magyarországi cigányság 1971-2003. Budapest, MTA Etnikai-nemzeti Kisebbségkutató Intézet. http://www.tankonyvtar.hu/ hu/tartalom/tamop425/2011_0001_542_02_A_magyarorszagi_ciganysag/ch01.html [Letöltve: 2019. 01. 12.]

Kozma T. (2013) Cigány, roma oktatás: európai körkép. Romológia folyóirat, No. 1. pp. 136138. http://romologiafolyoirat.pte.hu/?page_id=657. [Letöltve: 2018. 12. 20.]

KSH (2014) 2011. ÉVI NÉPSZÁMLÁLÁS - 9. Nemzetiségi adatok. http://www.ksh.hu/ docs/hun/xftp/idoszaki/nepsz2011/nepsz_09_2011.pdf [Letöltve: 2018. 11. 28.]

Kt. (1993) A közoktatásról szóló 1993. évi LXXIX. törvény 24. § (3).

Kurt Lewin Alapítvány (2010) A Roma Integráció Évtizede Program által megjelölt célok megvalósulási folyamatának monitoring-vizsgálata Magyarországon a 2005-2009 közötti idöszakra vonatkozóan. Budapest, 2010. http://www.romadecade.org/cms/upload/ file/9317_file3_decade_of_roma_inclusion_hu_fin.pdf [Letöltve: 2016.10.26.]

Lakatos Sz. (2018) A romani nyelv a kutatás és az oktatás tükrében. In: Cserti Csapó T. (ed.) Alapismeretek cigány, roma közösségekröl. Budapest, Magyar Cserkészszzövetség. pp. 87-106.

Liskó I. (2006) A hátrányos helyzetü tanulók iskoláztatási esélyei. Educatio, Vol. 15. No. 1. pp. 99-129. http://oitk.tatk.elte.hu/hu/node/40 [Letöltve: 2019. 01. 14.]

MAYER J. (2009) Képzésbe ágyazott foglalkoztatás. Budapest, Oktatáskutató és Fejlesztő Intézet. http://oktataskepzes.tka.hu/documents/7_Lifelong_learning/3_LLL_strat_ hatarokon_ativelo_fejl/2_2009_2010/2_Nemzeti_wsok/1WS_20090622/mayer_ jozsef_ea_2009_06_22.pdf [Letöltve: 2019.01.20.]

Miskovic, M. (ed.) (2013) Roma Education in Europe: Practices, Policies and Politics. London, New York, Routledge.

Németh Sz. (2009) (ed.) A tanoda-típusú intézmények müködésének, tevékenységének elemzése. Budapest, TÁRKI-TUDOK.

Nkt. (2011) A köznevelésről szóló 2011. évi CXC. törvény 45. § (2).

Orsós A. (2015a) Cigány/roma nemzetiségi oktatás. Pécs, Pécsi Tudományegyetem Bölcsészettudományi Kar Neveléstudományi Intézet Romológia és Nevelésszociológia Tanszék, Wlislocki Henrik Szakkollégium. http://wlislocki.pte.hu/sites/wlislocki.pte. hu/files/oldal_mo/cigany_roma_nemz_okt_bel_full.pdf [Letöltve: 2019. 01. 21.]

Orsós A. (2015b) A beás nyelv. In: Orsós A. (ed.) A romológia alapjai. Pécs, PTE BTK Neveléstudományi Intézet Romológia és Nevelésszociológia Tanszék - Wlislocki Henrik Szakkollégium. pp. 151-180. (ISBN [print] 978-963-642-821-1) http://mek.oszk. hu/14700/14735/html/index.html [Letöltve: 2019. 01. 21.]

Orsós A. (2018) A cigányság nyelvi csoportjai - szociolingvisztikai megközelítésben. In: Cserti Csapó T. (ed.) Alapismeretek cigány, roma közösségekröl. Budapest, Magyar Cserkészszövetség. pp. 69-86.

PApp Z. A. (2010) A romániai roma-magyar kötődésű népesség az 1992. és 2002. évi népszámlálási adatok tükrében. Regio, No. 1. pp. 96-140. http://epa.oszk. hu/00000/00036/00077/pdf/Regio_2010_01_096-140.pdf [Letöltve: 2019.01. 13.]

Pénzes J., Tátrai P. \& PÁsztor I. Z. (2018) A roma népesség területi megoszlásának változása Magyarországon az elmúlt évtizedekben. Területi Statisztika, Vol. 58. No. 1. pp. 3-26. (DOI: 10.15196/TS580101). http://www.ksh.hu/docs/hun/xftp/ terstat/2018/01/ts580101.pdf [Letöltve: 2019. 01. 12.]

Polónyi I. (2016) Emberi erőforrásaink 21. százada. Budapest, Gondolat Kiadó. 
Roma Education Fund (2007) Advancing Education of Roma in Bulgaria. Country Assessment and the Roma Education Fund's Strategic Directions. https://www.romaeducationfund.org/ sites/default/files/publications/bulgaria_report.pdf [Letöltve: 2019. 01. 14.]

Roma Inclusion Index (2015) Decade of roma inclusion secretariat foundation, september 2015. http://www.romadecade.org/cms/upload/file/9810_file1_roma-inclusion-index2015-s.pdf [Letöltve: 2016. 10. 26.]

Roma Integráció Évtizede 2005-2015 (2014) Kutatási Jelentés - Decade Intelligence. A romák társadalmi befogadását elömozditó projektek sikerességét vagy kudarcát befolyásoló tényezökröl. Roma Integráció Évtizede Titkárság Alapítvány. (ISBN: 978-963-08-9719. 8) http://www.romadecade.org/cms/upload/file/9791_file13_evtized-kutatasi-jelentes. pdf [Letöltve: 2016. 10. 27.]

Rorke, B., Matache, M. \& Friedman, E. (2015) A Lost Decade? Reflections on Roma Inclusion 2005-2015. Budapest, Decade of Roma Inclusion Secretariat Foundation. https://www.rcc.int/romaintegration 2020/romadecadefold//decade\%20 implementation/5.\%20Decade\%20Secretariat\%20Reports/A\%20Lost\%20Decade.pdf [Letöltve: 2019. 01. 14.]

SÁndor-Schmidt B. (2016) A bulgáriai cigányok. Romológia folyóirat, No. 11. pp. 63-74. http://romologiafolyoirat.pte.hu/wp-content/uploads/2018/01/romologia_11_BELIV_ PRINT_FULL.pdf [Letöltve: 2019. 01. 12.]

Szabóné Kármán J. (2008) A roma/cigány népesség helyzete. In: Kopp M. (ed.) Magyar lelkiállapot. Budapest, Semmelweis Kiadó. pp. 415-427.

Trendl F. (2018) Szocializáció és a magyarországi cigányság iskolázottsága. In: CserTi Csapó T. (ed.) Alapismeretek cigány, roma közösségekröl. Budapest, Magyar Cserkészszövetség. pp. 149-164.

Trendl F. (2019) Végzettségi és lemorzsolódási adatok a Wlislocki Henrik Szakkollégiumban 2013 és 2018 között. In: Szemenyei M. \& Schäffer J. (eds) Sikerek és kibivások. A pécsi roma szakkollégiumi program összegzése. Pécs, Pécsi Tudományegyetem Bölcsészettudományi Kar Neveléstudományi Intézet Romológia és Nevelésszociológia Tanszék, Wlislocki Henrik Szakkollégium. (ISBN 978-963-429-303-3) Megjelenés alatt.

VAŇo, B. (2011) Demografická charakteristika rómskej populácie v SR. Bratislava, Akty.

VARGA A. (2012) A cigányságot érintö hazai oktatáspolitikai változások. Előadás. Mandulavirágzási Tudományos Napok, Pécs. http://www.mandula.pte.hu/index. php?p=contents\&cid=402 [Letöltve: 2019.01 .14 .]

VArga A. (2015) Az inklúzió szemlélete és gyakorlata. Pécs, Pécsi Tudományegyetem Bölcsészettudományi Kar Neveléstudományi Intézet Romológia és Nevelésszociológia Tanszék, Wlislocki Henrik Szakkollégium. http://wlislocki.pte.hu/sites/wlislocki.pte. hu/files/oldal_mo/inklu_02_beliv_nyomda.pdf [Letöltve: 2019. 01. 14.]

A cikk a Creative Commons Attribution 4.0 International License (https://creativecommons.org/licenses/ by/4.0/) feltételei szerint publikált Open Access közlemény, melynek szellemében a cikk bármilyen médiumban szabadon felhasználható, megosztható és újraközölhető, feltéve, hogy az eredeti szerző és a közlés helye, illetve a CC License linkje és az esetlegesen végrehajtott módosítások feltüntetésre kerülnek. (SID_1) 